"Microfinance strategy and its impact on profitability and operating efficiency: evidence from Indonesia"

\begin{tabular}{|c|c|}
\hline AUTHORS & Saladin Ghalib \\
\hline ARTICLE INFO & $\begin{array}{l}\text { Saladin Ghalib (2017). Microfinance strategy and its impact on profitability and } \\
\text { operating efficiency: evidence from Indonesia. Investment Management and } \\
\text { Financial Innovations, } 14(2), 51-62 \text {. doi:10.21511/imfi.14(2).2017.05 }\end{array}$ \\
\hline DOI & http://dx.doi.org/10.21511/imfi.14(2).2017.05 \\
\hline RELEASED ON & Friday, 02 June 2017 \\
\hline RECEIVED ON & Friday, 10 February 2017 \\
\hline \multirow[t]{2}{*}{ ACCEPTED ON } & Thursday, 30 March 2017 \\
\hline & $(c c)$ EY-NC \\
\hline LICENSE & $\begin{array}{l}\text { This work is licensed under a Creative Commons Attribution-NonCommercial } 4.0 \\
\text { International License }\end{array}$ \\
\hline JOURNAL & "Investment Management and Financial Innovations" \\
\hline ISSN PRINT & $1810-4967$ \\
\hline ISSN ONLINE & $1812-9358$ \\
\hline PUBLISHER & LLC "Consulting Publishing Company "Business Perspectives" \\
\hline FOUNDER & LLC "Consulting Publishing Company "Business Perspectives" \\
\hline
\end{tabular}

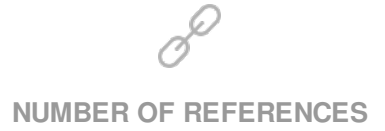

35
NUMBER OF FIGURES

0
NUMBER OF TABLES

4

(C) The author(s) 2022. This publication is an open access article. 


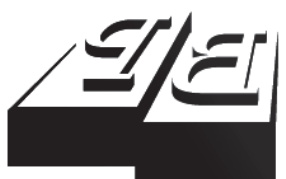

BUSINESS PERSPECTIVES

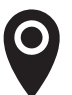

LLC "CPC "Business Perspectives" Hryhorii Skovoroda lane, 10, Sumy, 40022, Ukraine

www.businessperspectives.org

Received on: $10^{\text {th }}$ of February, 2017 Accepted on: $30^{\text {th }}$ of March, 2017

\section{(c) Saladin Ghalib, 2017}

Saladin Ghalib, Department of Business Administration, Faculty of Social and Political Science, The University of Lambung Mangkurat, Indonesia.

\section{(ㄷ)(1) $(8$}

This is an Open Access article, distributed under the terms of the Creative Commons AttributionNonCommercial 4.0 International license, which permits re-use, distribution, and reproduction, provided the materials aren't used for commercial purposes and the original work is properly cited.

\title{
MICROFINANCE STRATEGY AND ITS IMPACT ON PROFITABILITY AND OPERATING EFFICIENCY: EVIDENCE FROM INDONESIA
}

\begin{abstract}
After the Asian crisis in 1998, Indonesian banking transformed very quickly into more market-oriented banking. This development increased the competition, on the one hand, and pressure to perform better financially, especially after foreign investor taking over the ownership, on the other hand. Some banks transformed their business strategies into a microfinance bank for profit motives. Such strategy jointly results in significant profitability and efficiency. Using SUR regression, it is found that for the profitability equation, the profitability relates to the size of the bank, the loan loss reserve to gross loan (LLRGL), equity ratio (ETA) and fixed asset ratio (FIXASEQ). For operating efficiency (CIR), the result is similar and only the sign is different. Interestingly that for profitability, the microfinance strategy (MFS) is significant, but not for operating cost efficiency. It implies the need for more cost efficient commercial banks entering microfinance business as it will benefit small borrowers in terms of lower interest margin.
\end{abstract}

\section{Keywords}

JEL Classification microfinance, efficiency, profitability, SUR regression, banking strategy

G32

\section{INTRODUCTION}

Indonesia has experienced a restructuring and consolidation process in the banking industry since 2000 as result of Asian crisis in 1998 . Recapitalization, government intervention, privatization are expected to foster operational efficiency and improve healthy competition in the banking market. The impact of these events is noticed in terms of profitability, capital adequacy and business models. Some banks transformed their business strategy from corporate-oriented into small business and mass market known as microfinance strategy.

Doing microfinance means the provision of banking service in terms of saving and lending to poor clients. It means the size of saving or loan per clients is very small. However, the market for this bottom line is so huge. Banking crisis in 1998 has tranformed the banking industry into more private and profit-oriented business as the consequencies of banking privatization. Experience of Bank Rakyat Indonesia (BRI) as the only state bank survived during the crisis has been an example how microfinance bank is immune to the crisis, as it involves a perfect loan diversification.

After the period of crisis, the landscape of banking sphere changed from the agent of the development to more profit-oriented. The crisis making the liberal economic ideology is politically stronger, especially under the 
IMF Supporting Program. The market mechanism guides the economy, in general, and the banking industry, in particular. It makes bank business a way to earn profit only. Banks also innovate in payment and lending service. As a response, significant change happened when the strategy is by downsizing the target market. A bank that serves mass market is less risky but profitable. More banks, then, enter the mass market. These banks are copying what BRI has done.

Murdoch (2000) produces a paper that discusses the popularity of the microfinance as a multifaceted tool to solve world problems such as poverty, women's participation, and income disparity. The failure in the early 1990s should be prevented, as microfinance institutions (MFI) rely on donor and subsidy. He suggested to rethink MFI and mapped a new avenue for constructing foundations for a next wave of microfinance innovation. This conclusion helps reform subsistence-market arguments to be away, as appropriate size of microfinance can be profitable.

Yunus (2011) posits that microfinance institutions ideally practice social businesses principle and use business for social missions. It means a bank doing microfinance has responsibility to conduct business not just as business as usual, but also involves social mission. The problem with microfinance is the high interest rate for the borrowers to cover cost of funds and operational cost. It means banks could have substantially reduced interest rates, as the funds are substantially lowered for banks. The better position in the market should also mean that the penetration into the mass and low market by banks does not mean to driving out the established microfinance. The lower price is to encourage the market to reduce the price of the loan.

Ideally, banks doing microfinance business should follow Baydas, Graham and Valenzuela (1997) that they must apply new technologies, explore new technologies to expand lending, new independent profit or costoriented strategy. Ideally, microfinance banks should make all effort not only by increasing interest rates to borrowers but by reducing costs. This paper is inspired by paper written by Shaban, Duygun, Anwar and Akbar (2014), which studies small business lending from the Islamic bank and conventional bank perspectives. The objectives of this paper are as follows:

To determine the impact of microfinance strategy on banking profitability and cost efficiency.

To test if the decision to enter the microfinance business influences both eficiency and profitability of the banking sector in Indonesia. These two objectives will end up to conclude whether the banks doing microfinance activities have achieved their profitability and cost efficiency target.

\section{LITERATURE REVIEW}

Elayd and Harrison (2010) studied the motivations of the banking industry to downsize the business into microfincance. This strategic choice is to tap the lower subsistence markets of the pyramid. The strategy is to expand the market so the economies of scale are expected. It can be done by adopting a serious effort to build experience, knowledge and skill, in very short time, so the banks can enjoy the competitive advantage compared to traditional microfinance industry. Using samples from two commercial banks that apply micro financing business strategies in Sri Lanka, they found these banks enjoyed higher profitability. They also contributed to the society in terms of poverty eradication program.
Isern and Porteous (2005), from CGAP, summarized various studies on microfinance banks. They observed that a bank with a microfinance business may benefit from greater "staff motivation as they assume to help the poor". Further, it also increases the commercial drive as it provides higher margins. Further, it also improves sense of purpose and accountability than traditional lending.

Bounouala and Rihane (2014) point out that the strategies of commercial banks entering microfinance business should follow their own fitness considering bank specific characteristic and the environment in which bank operates. However, all strategies should consider high volume of operations to reach the bottom of the market, as fast and 
efficient process to clients operating in the informal and subsistence economy. More personal approach is required as the clients are traditionally marginalized from traditional financial providers. Banks must have a better risk management system to support before and after loan disbursement.

However, the strategy to provide loan services to more customers from lower income group in order to enjoy economies of scale benefit can lead to an increase in problem loan if not done properly. Ault and Spicer (2014) suggest a bank doing microfinance should contribute to poverty eradication by reducing cost of borrowing. In general it can use modern technology to expand the market but at the same time reduce the operating cost inefficiency. MFIs of the large size that have more loyal customers tend to close to their sustainability level.

Unfortunately, according to CGAP (1998), many banks entering the Commitment to do microfinance are mostly relying on a personal commitment from the board of directors rather than on the institution's vision and mission. As a result, the initial failure brings the program into collapse. Except for BRI, this bank is built on the historical foundation as a farmer microfinance. Fortunately, as a business entity, commercial bank in microfinance from the developing countries, regard microfinancing activities only for social mission but also as profitable business. Further, experience provides evidence that a strong and continuing commitment as a key factor for bank business in the microfinance lending. It implies that when the government wants to develop microbanking program, the commitment is the key consideration.

According to Bassem (2009) experiences, it shows that microfinance institution, in general, is a lack of governance. They mostly rely on the vision of the owner. At the same time, governance is very important for the profitability of the MFI. To do this, the MFI can increase its governance through the mechanisms, practice of external governance especially the pressure from the donors. It is a strength of bank that enters the microfinance business when its governance is well institutionalized. It does not mean profit and serving of the lower market or outreach is mutually exclusive. Earning profits is still possible while serving the poor. However, as Cull and Morduch (2007) stressed, a trade-off between profitability and serving the poorest exists and bank doing microfinance should be aware of it and do all necessary action to ensure that it is in line. They warned that raising fees and interest to extremely high levels can be a contradiction for profitability.

In Jordan's case, Al Atoom and Abu Zerr (2012) witness that successful microfinance business requires macroeconomic stability and microeconomic strength to reach a consistent sustainability. Their study concludes that Jordanian MFIs have more financial sustainability than those of other Arab and Asian countries because of the combination of macroeconomic stability and internal governance.

Study by Ahmed, Bhuiyan, Ibrahim and Said (2016) concludes that the ages of the operation are not guaranteed for a profitable microfinance business. They must minimize operating costs and expenditures per borrower to be efficient. As a microfinance business requires a strong customer foundations, they must prevent losing active borrowers. Their study also confirms that MFIs in South Asia in majority enjoy a profit measured by ROA and ROE.

However, due to only for profit orientation, microfinance banks are reluctant to lend to newly established business venture or start-up business. Microfinance banks prefer to finance small, established SMEs to expand than to provide a very potent new start up.

Sufian and Habibullah (2009) investigate the profitability of commercial banking in China and find that bank-specific variables such as liquidity, credit risk, and capitalization have significant and positive impacts for the state owned banks. This profitability comes from higher credit risk taking. Further, economic growth is also positive and significant. Tahir and Abdul (2011) using sample from ASEAN banking market found that profitability is related to internal bank and governance environments, such as personnel expense ratio, regulatory capital ratio, net loan, cost efficiency, corruption and macroeconomic variable. They found that the corruption index is positive and significant to profitability. 
Berger and DI Patti (2006) proposed two hypotheses on the impact of capital known as the efficiencyrisk hypothesis and the franchise-value hypothesis. The first hypothesis states that equity capital serves as protection against the bankruptcy, as it makes banks more efficient. The second hypothesis related to the franchise-value focuses on higher profit by holding more equity capital. Both hypotheses assume the importance of capital in the banking business.

Molyneux and Thornton (1992) posit that the equity capital ratio improves banks' performance. It implies that there is a positive relationship between equity capital and profitability. Similar result is presented by Demirguc-Kunt and Huizinga (1999) that conclude better capitalized banks performed better than less capitalized banks. For efficiency, Gardener, Molyneux and Nguyen-Linh (2011) find similar impact on cost efficiency.

The impact of size is also important. McAllister and McManus (1993) find positive impact of size on the profitability. This is a result of economies of scale. It means large size banks enjoy better profitability. Efficiencyis also very important for profitability. Study by Tan and Floros (2012) provide empirical evidence that cost efficiency has impact on profitability.

The impact of capital on the cost efficiency was investigated by Kasman, Tunc, Vardar and Okan (2009). They conclude capital adequacy reduces costs due to banks' creditworthiness in the market that reduces cost borrowing. Schweiger and Lieberg (2009) find that less capitalized banks are becoming more risk taking and then the market penalizes them. Low capitalized bank own less reputation in the competitive market as it is viewed as risky. As a consequence, the bank has to pay a higher interest for its borrowings in the market. That is why the equity to total assets (ETA) ratio is viewed as risk preference indicator. Banks with higher ratio tend to take less risk. Assuming the size is in line with capital ownership, Karim (2001) stated that large sized banks are more cost efficient than smaller ones.

Dichter and Harper (2007) stated that there was mission drift in the microfinance industry. The microfinance industry is flourishing but there is a risk that microfinance players are abandoning their mission to serve the poor. Yunus (2011) pointed out that financially better off clients crowd out poorer clients in any credit scheme because they borrow more and with better collateral so their credibility is higher than the one of poor borrowers. The initial mission of microfinance institutions (MFIs) is to provide banking services to the poor, that is, to lend very small sums to very poor borrowers. If the bank considers either financially better or poor clients, it is not purely defined as microfinance bank. It is a bank purely. However, a study by Mersland and Strom (2010) shows that the mission drift hypothesis is not confirmed. Microfinance is still microfinance as it is.

Resengard's (2004) study on the BRI concluded that social entrepreneurship can create profits and add social value. Financial institutions like BRI serve the bottom line a market can enjoy profits, making millions of people better off and financially sustainable. In short, a successful bank doing microfinance can mean for the bank to sustain and for helping sustain the communities the bank serves.

Martinez (2015) concludes that MFI increasing outreach to women has a positive impact on the operational self sufficiency, the returns on assets (ROA) and outreach to women or social impact. Unfortunately, rent-extraction (charging high interest) still exists in most commercialized firms doing microfinance business. This type of MFI has competitive advantages due to market share rather than the quality of the services offered. In general MFI can reach the poor with goods, services and opportunities in commercially viable ways, doing well by doing good at the same time. Unfortunately, commercial MFI is more on exploiting entire difference.

Credit risk is negative to cost efficiency. Berger and De Young (1997) stressed the role of non-performing loans (NPL) on bank cost efficiency. A large proportion of non performing loans generate extra expenses that reduce bank's cost efficiency. In contrast, reducing cost, in short term, may increase bank cost efficiency, but in the near future, it will increase problem loan and reduce the cost efficiency, because banks must spend more resources to recover the problem loan. Tahir et al. (2012) study the determinants of cost inefficiency of banks in ASEAN and conclude that bank specific variables and economic growth contribute to efficiency. Hsiao, Shen 
and Bian (2015) study the cost and profit efficiency of the Chinese domestic banking after financial reform. They conclude that the advancement in technologies and better trained bank's staff improve the efficiency.

Interesting empirical result from Indonesia is provided by Shaban, Duygun, Anwar and Akbar (2014) that big banks are not eager to provide loans to small business (Small and micro enterprises) as it is risky and costly. Unfortunately, both Islamic and conventional banks are behaving similarly. They also test the diversification impact of lending to small business and find it is not significant for conventional banks but significant for Islamic banks. On the profitability impact, researchers found that small business lending is significant to profitability and it is the motivation of banks to involve in the small business lending. Islamic banks prefer to lend to small business as they provide a diversification effect as there are implicit subsidies by the banking authority lending to small business enjoying less capital requirement.

\section{METHODS}

In this study, we apply multiple linear regression. There are two dependent variables and seven predictor variables. The initial model is presented as follows:

$$
Y_{i}=\mathrm{B}_{0}+\beta_{1} X 1_{i}+\beta_{2} X 2_{i}+\beta_{3} X 3_{i}+\varepsilon_{i}
$$

where $Y_{i}$ - dependent variable,

$X_{i}$ - independent variable,

$\beta_{i}-$ coefficient.

The seemingly unrelated-regression (SUR) regression is the most appropriate method in discussing the interrelationship between cost efficiency and profitability, when the banks have a different strategic policy. This technique is superior compared to ordinary least squares (OLS) as it can include errors in the model and will provide better results. The superiority is also the result of the technique of estimation that applies the maximum likelihood method. Our concern is because the profitability and cost efficiency are related. Cost efficiency will influence the profitability and the rela- tionship should be endogenous. We apply multiple linear regression.

We apply seemingly unrelated regression (SUR) with two equation models. Cross section data of selected sample are used to determine profitability and cost efficiency of selected Indonesian bank. The panel data set is used for this study from 2008 to 2014. Referring to Greene (2012), this system equation of the 2 seemingly unrelated regression equations is presented below:

$$
\begin{aligned}
& y_{1}=X_{1} \beta_{1}+\mu_{1}, \\
& y_{2}=X_{2} \beta_{2}+\mu_{2},
\end{aligned}
$$

where $y_{i}$ is a dependent variable, $X_{i}$ is a dependent variable and $\mu_{i}$ is error term. In SUR regression, $y_{i}$ is a $T$ column vector of observations for dependent variable, while $X_{i}$ is a $T \times K$ matrix of observations for independent variables.

\subsection{Variables}

There are nine variables used in the study to analyze the determinant of Indonesia's banking profitability and operating cost efficiency. The two variables are treated as dependent variables and the rest of variables are considered as independent or explanatory variables. We only use bank-specific, as independent variables are treated as internal bank variable. We apply the microfinance strategy as dummy for the independent variable. All variables are generated from a financial report from the income and balance sheet statements. Please note that the data is annual frequency data and treated as bank-specific variables.

\subsubsection{Dependent variable. There are two dependent variables for this study.}

1. ROA is the ratio of profit before tax divided by total asset and it indicates the capability of the firm to generate profit from asset usage.

2. Operating efficiency (CIR). The operating efficiency represented by total operating expenses to total expenses. The operating efficiency reflects the ability of bank management to generate income from every unit it spends. The lower ratio leads to the better cost efficiency. A higher ratio is not good as it is not efficient. 


\subsubsection{Independent variables. They are presented below.}

1. LASSET is the logarithm of asset size. It is used in the literature of finance to measure the benefit of cost saving due to economies of scale. The bank size is expected to have positive impact on the profitability. For operating efficiency, it should be negative.

2. ETA is the ratio of equity capital to total asset. The capital ratio provides information on the strength of bank's equity capital. It is measured by dividing total equity capital with its total assets. The higher ratio impacts on higher bank's profitability and improves its efficiency. Positive relationship is expected from the equity capital to total assets ratio (ETA). Banks with credibility will enjoy higher efficiency because of lower chance of bankruptcy which decreases the risks and costs of funding. For operating efficiency it should be negative.

3. LLRGL is asset quality indicator. It is used to measure the asset quality and generated by dividing loan loss provision to total loan. The higher ratio indicates higher risk. As the data on non-performing loans is not available across banks, so we use this as a measure of loan quality. It should be negative to profitability and positive to operating efficiency.

4. Liquidity (LIQDEP) is derived from liquid asset divided by customer funds. This variable indicates the liquidity position of banks. The higher percentage of ratio means more liquid. There are two possible impacts on performance: improve performance and hinder performance. It can be positive as well as negative between liquidity and profitability and efficiency.

5. DER is gearing ratio calculated by ratio of debt to equity. The capital of bank can serve as a cushion from financial losses. The bank capital also provides a cushion from bankruptcy if the bank's assets value fall or bank's loans are not paid back. Lower ratio of total debt divided by total equity. It is expected to have positive or negative both for profitability and operating cost efficiency.

6. MFS is strategic decision variable. When a bank is doing microfinance business, the value is 1 and if not, the value is zero. There are two possible impacts on profitability and cost efficiency.

7. FIXASEQ is the ratio of the fixed assets to total equity. It can be positive as well as negative for the profitability and operating efficiency.

Table 1. Variable, measurement and expected result

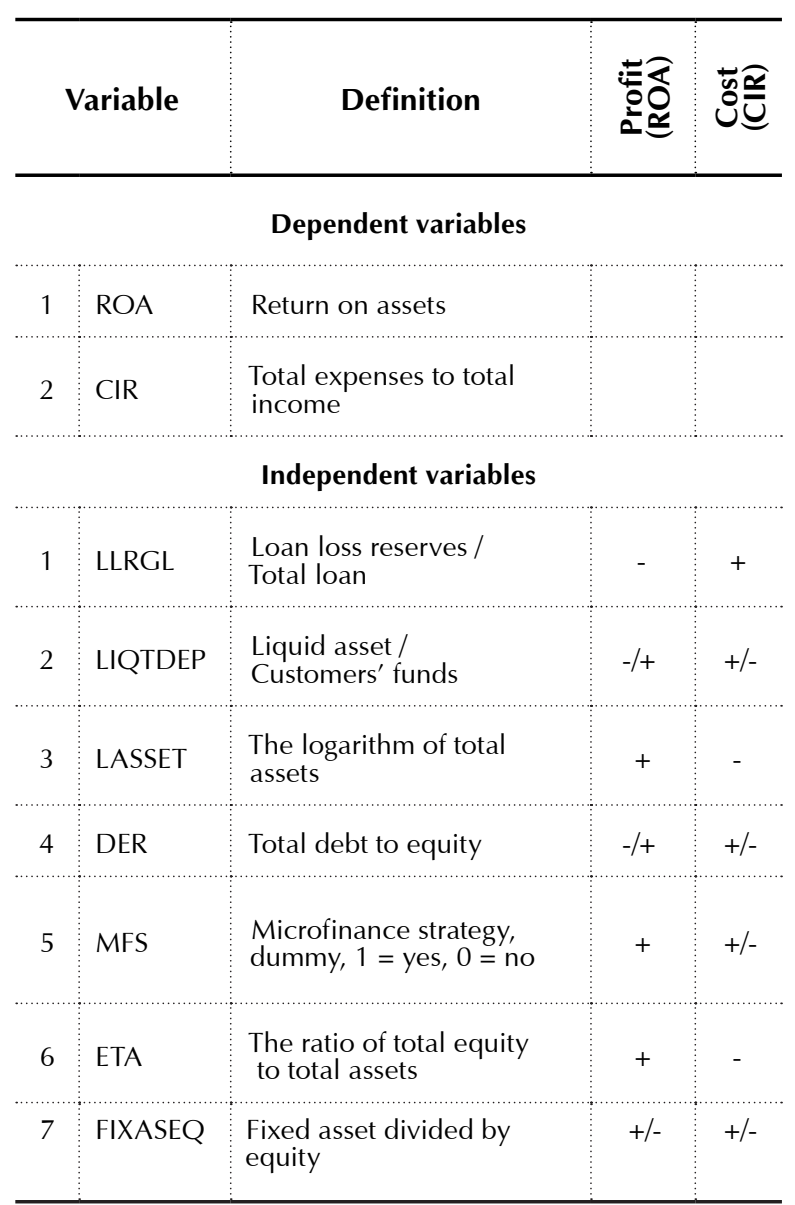

The empirical models are presented below. Formula (4) is used to test the impact of microfinance strategy (MFS) on profitability (ROA). Formula (5) is to test the impact of microfinance strategy (MFS) on bank operating cost efficiency (CIR).

$$
\begin{aligned}
& R O A=a+b 1 \cdot L L R G L+b 2 \cdot L A S S E T+ \\
& +b 3 \cdot D E R+b 4 \cdot M F S+b 5 \cdot E T A+ \\
& +b 6 \cdot F I X A S E Q+e \\
& C I R=a+b 1 \cdot L L R G L+b 2 \cdot L A S S E T+ \\
& +b 3 \cdot D E R+b 4 \cdot M F S+b 5 \cdot E T A+ \\
& +b 6 \cdot F I X A S E Q+e .
\end{aligned}
$$




\section{RESULTS}

Table 2 presents the descriptive statistics of the variables in this paper. For the ROA, we can find that the maximum is $7.97 \%$ and the minimum is $-10 \%$. Standard deviation is larger than its mean value indicating the variability of the ROA. For the operating efficiency (CIR) the most efficient is $13 \%$, meaning to generate 100 , bank spends only 13 . However, on average, the spend is $63 \%$. The loan loss provision is relatively in the tolerable condition as the maximum is less than $10 \%$. Further investigation shows that bank doing microfinance is slightly higher $(2.5 \%)$ compared to the non microfinance bank $2.5 \%$. On average, bank allocates $11 \%$ of its deposit to finance liquid assets. For leverage (DER), banks borrow seven times of its equity. For the ETA, it is 13.55 meaning only $13 \%$ of bank assets come from shareholders. Banks are also very reluctant to spend for fixed assets.
Table 3 depicts the correlation among variables in this study. ROA and CIR are negatively correlated and very high. It is because cost and efficiency are very much related. LLRGL is also negative meaning high LLRGL will reduce profitability. Asset size is positive and significant. Strategy to enter microfinance business is also positive, indicating the contribution of the strategy to increase profitability. Equity is also positive to profitability. The fixed asset ratio is negative to profitability implying the need for outsourcing in providing fixed asset to support bank operation.

For operating efficiency (CIR), the correlation is positive to loan loss provision (LLRGL), fixed asset ratio (FIXASEQ) and liquidity (LIQDEP). Strategy (MFS) is positive, but very low, indicating the ability of banks doing microfinance to manage the cost. ETA and Size (LASSET) are all positive to cost reduction.

Table 2. Descriptive statistics

\begin{tabular}{|c|c|c|c|c|c|c|}
\hline & Variable & Obs & Mean & Std. dev. & Min & Max \\
\hline 1 & ROA & 436 & 0.01377156 & 0.01631459 & -0.1032 & 0.0797 \\
\hline 2 & CIR & 436 & 0.6309314 & 31.3389 & 13.76 & 340.56 \\
\hline 3 & LLRGL & 436 & .024751 & .0515816 & $4.82 \mathrm{e}-06$ & .9068441 \\
\hline 4 & LIQTDEP & 436 & .1117137 & .0807053 & .0074627 & .9648376 \\
\hline 5 & LASSET & 436 & 14.20023 & 1.597319 & 10.04807 & 18.0459 \\
\hline 6 & DER & 436 & 7.498633 & 4.638117 & -28.44734 & 46.55793 \\
\hline 7 & MFS & 436 & .0642202 & .2454264 & 0 & 1 \\
\hline 8 & ETA & 436 & .1344906 & .0787127 & -.0328 & .6422 \\
\hline 9 & FIXASEQ & 436 & .0000229 & .0001112 & -.0014738 & .0013928 \\
\hline
\end{tabular}

Table 3. Correlation matrix

\begin{tabular}{|c|c|c|c|c|c|c|c|c|c|}
\hline ROA & 1.0000 & & & & & & & & \\
\hline CIR & -0.7849 & 1.0000 & & & & & & & \\
\hline LLRGL & -0.2144 & 0.2817 & 1.0000 & & & & & & \\
\hline LIQTDEP & -0.0859 & 0.1376 & 0.2705 & 1.0000 & & & & & \\
\hline LASSET & 0.2880 & -0.3245 & 0.0199 & 0.0496 & 1.0000 & & & & \\
\hline DER & -0.0308 & 0.0920 & 0.0746 & -0.0378 & 0.2465 & 1.0000 & & & \\
\hline STRATEGI & 0.1488 & -0.0750 & 0.0039 & 0.0293 & 0.1537 & -0.0783 & 1.0000 & & \\
\hline ETA2 & 0.1855 & -0.0546 & -0.0487 & 0.0172 & -0.3913 & -0.6025 & 0.0419 & 1.0000 & \\
\hline FIXASEQ & -0.1589 & 0.3733 & 0.0623 & 0.1261 & -0.2576 & 0.2130 & -0.0203 & 0.2056 & 1.0000 \\
\hline Variable & ROA & CIR & LLRGL & LIQTDEP & LASSET & DER & STRATEGI & ETA2 & FIXASEQ \\
\hline
\end{tabular}


From the regression results, we find the interesting point that supports microfinance strategy as a positive effort for improving profitability, but not making the ban inefficient. In this study we employ 436 bank observations. For profitability equation (model 1), we find the R-Squared is $24 \%$ and for efficiency equation (model 3), the R-Squared is 33\%. In general, it is relatively low. However, the R-Squared statititc is less useful in the SUR regression. F-statitic is 23.95 for Model 1 and 29.27 for Model 2. Both are siginificant at $1 \%$ meaning we can use it for further analysis. Correlation matrix of residuals is -0.75 and siginifcant at $1 \%$. According to Breusch-Pagan test of independence, Chi-squared is 242.519 and significant at $1 \%$.

Table 4. The SUR regression result

\begin{tabular}{|c|c|c|c|}
\hline & Variable & Profit & Cost \\
\hline 1 & LLRGL & $-6.19^{* * *}$ & $150.18^{* * *}$ \\
\hline 2 & LIQTDEP & -0.55 & 17.35 \\
\hline 3 & LASSET & $0.37^{* * *}$ & $-6.55^{* * *}$ \\
\hline 4 & DER & $0.09 * * *$ & -0.71 \\
\hline 5 & STRATEGI & $0.59 *$ & -1.80 \\
\hline 6 & ETA & $10.53^{* * *}$ & $-122.84^{* * *}$ \\
\hline \multirow[t]{2}{*}{7} & FIXASEQ & $-3014.57^{* * *}$ & $99142.36^{* * *}$ \\
\hline & Cons & $-5.73^{* * *}$ & $170.12^{* * *}$ \\
\hline
\end{tabular}

Note: ${ }^{\star}=1 \%,{ }^{* *}=5 \%,{ }^{* *}=1 \%$.

\subsection{Profit equation}

The size of the bank (Lasset) is positive and significant. It means the big banks are more profitable than smaller ones. It is rational as the big bank can enjoy economic efficiency to scale and scope. The bank enjoys lower average costs as it can spread the cost to a different unit and size. Literature on bank efficiency always stresses the benefit of size in bank efficiency study. Microfinance bank, such as BRI, is already having networks around Indonesia, and they also enjoy reputation benefit, especially related to the cost of funding. Big banks enjoy cost efficiency both from asset side, liability side and operation side.

In relation to capital strength, the bank owning high debt to equity ratio (DER) is more profitable. The DER is positive and significant at $1 \%$. This is rational as bank capital is much lower than its debt. Optimal debt in terms of short term deposit or long term borrowing can be transformed into productive assets. In Indonesia bank can enjoy interest margin at $15 \%$, when doing microfinance as the lending rate is high. As previously mentioned, bank chose to exploit the interest rate for profit not the cost of doing business.

Strategy to enter microfinance busines is a correct decision. We can see here that the coefficient MFS is 0.54 and significant at $1 \%$. This finding is consistent with the fact that microfinance banks are profitable. BRI and BTPN are always the top performers in terms of profit. Up to now, BRI is the most profitable in terms of the size of profit, although it is only the third largest bank. This result comes from its microfinance business. It means doing microfinance strategy is the right choice. It is supported by the fact that microfinance strategy is jointly given the significant impact on profitability and efficiency. The Chi-squared is 8.02 and significant at $1 \%$. It means microfinance strategy is important for the bank.

Capital (ETA) is also significant at $1 \%$. It means that bank with stronger capital is more successful than that with lower capital. There are two reasons for this situation. Stronger capital means the bank to use its excess capital for loan origination. It generates profits. Bank can also use the excess capital for investing in facilities that improve the efficiency of the operation. Related to regulatory capital, bank with stronger capital position will have the capacity to expand to provide loan for wider market, especially in the mass market.

The fixed asset to equity ratio (FIXASEQ) is negative and significant indicating the importance of this variable in the bank profitability. Bank that spends too much on fixed asset will have lower profitability, as the capacity of equity for productive investment is lower and cost to maintain the fixed asset is not cheap. There is a tendency in the banking industry to outsource the supporting asset, such as office and vehicles as it is not economi$\mathrm{cal}$. This finding supports such policy as the banks will enjoy better off, if they do not own the assets. The constant is -5.73 meaning the profitability is a result of effort. To be profitable bank must make effort to make it positive. It is different from the cost that is positive and to reduce it, bank must make it lower. 


\subsection{Cost efficiency equation}

The second model is the cost efficiency model (Model II). It explains how the microfinance strategy impacts on cost efficiency. From the SUR regression result we have R-squared equal 33\%. It means the model can explain $33 \%$ of variability in the cost efficiency. It is relatively low. However, the usefulness of $\mathrm{R}$-squared in the SUR regression is relatively low, as it is not purely ordinary least square (OLS). From the Chi-squared distribution statistics, we get 208 and confirm the model is significant at $1 \%$.

The Loan loss reserve to gross loan (LLRGL) is positive and significant at $1 \%$. It means any increase by $1 \%$ in the LLRGL, will generate inefficiency by $1.5 \%$. This result underlines the importance of credit risk management for the banks in the sample. From this perspective, preventing the credit default is the main interest of bank management. It is common feature in the country, where the bank is the main source of financing. Indonesia is the bank based financial system, where the bank is dominant as the financial system. This finding is consistent to model 1 which results are negative for profitability.

Liquidity is positive but not significant. It means bank that owns excessive liquidity position will be inefficient. This result is in line to the cost of funds and cost to maintain liquidity position. As the cost of the fund is expensive, putting more resources in the liquidity means having to incur costs of funds and lower yield at the same time. We are aware that investing in liquidity assets generates less income compared to investing in loan origination. The result is consistent with model 1 on bank profitability.

Under the theory of economy of scale, the bank is more efficient, when it can enjoy economies of scale and scope. Our finding shows that asset size is negative and significant at $1 \%$. It means big banks enjoy lower cost of operation. In other words, bank with higher asset value will be more efficient. The coefficient is -6.55 meaning that any one point increase of asset will improve efficiency by $6.55 \%$. This result is consistent to model 1 on profitability. This finding may imply that banking restructuring is necessary for improvement in efficiency.

The debt to equity ratio is not significant but positive to efficiency. Out result shows that leverage im- proves efficiency. It means the ability to attract external funding is positive for bank efficiency. However banks cannot exploit this without limit, as there are capital regulations that may restraint such policy. Although the sign is consistent with the Model 1 but the significance is different.

Interestingly, the microfinance strategy (MFS) is negative and not significant. It means, the strategy for microfinance business is positive to bank efficiency, although it is not significant. It means, there is misunderstanding among making strategies that entering microfinance business is costly and generates inefficiency. Our result shows that it is not the case.

Of course, entering microfinance business incurs more costs for loan origination and maintaining the portfolio. However, the interest margin is relatively higher compared to business loan. It means, by assuming the capacity to maintain loan quality, entering microfinance business is still very profitable strategy. It is especially so, when the bank has reached optimal level of outreach and size.

The variable of equity capital to asset (ETA) is negative and significant. The coefficient is 122.64 meaning the substantial effect of equity to efficiency. This result supports the expectation of the banking authority that requires banking industry to put more capital for efficiency and stability. This result shows that improving capital will improve efficiency. There are two explanations on this matter. The first is based on market discipline hypothesis. Under this framework, bank that owns strong capital position is regarded as the safe haven to investment. This will reduce the cost of borrowing and improve cost efficiency. Lower cost of fund means bank has capacity to exploit the market for profit. When banks can provide loan with lower cost of lending, bank will have ability to select the prospective borrower for improving quality.

The fixed asset to equity (FIXASEQ) is positive and significant. The coefficient is very big meaning it will give substantial impact on the efficiency. When banks spend most of its capital to finance fixed assets, bank will be inefficient. Fixed assets in the bank can support the operation of the bank. When bank own, the fixed asset, banks do not have to pay for the use. It should improve the cost efficiency. In opposite, the ownership of fixed assets implies the costs of depreciation and maintenance. From the finding, we can 
infer that renting the fixed assets for the vendors is more cost efficient than owning the asset. Other explanation is inability of the bank to use the equity fund for loan origination. This managerial issue involves the selection of resources allocation.

From the discussion above there is a consistency between the expected results and empirical one. On the credit risk side, the result between profit and cost efficiency model is consistent as it reduces the profitability (ROA) and increases inefficiency (CIR). Both are significant at $1 \%$. It means, whether a bank is doing microfinance or not, credit risk is very significant risk and must be managed consistently and thoroughly from time to time. Preventing and reducing credit risk is never ending process. In microfinance bank, the effort is much larger as the borrowers are in extraordinary numbers. As a comparison, a debtor in corporate loan department can be similar to 10.000 clients in microfinance unit. This result is consistent to Berger and De Young (1997), Tahir et al. (2012). It is also in line to Athanasoglu, Brissimis and Delis (2008) for the Greek banking market, which credit risk has negative and significant relation to the profitability. Srairi (2009) found that loan loss provision ratio has a negative and significant influence on the profitability (ROA) for Gulf Cooperation Countries (GCC) banking.

The impact of size is positive and significant for profit efficiency, but negative and significant for the cost efficiency. The result is consistent with other studies such, as Berger and Humphrey (1997), DemirgucKunt and Maksimovic (1999), Sufian and Habibulah (2009), and recently with Dawood (2014) who inferred that the size of bank has a positive influence on ROA due to economies of scale. Our results are consistent to Hughes and Mester (2013) that size is a matter for cost efficiency, as banks enjoy implicit support from too-big-to-fail principle, technological advantages in terms of diversification of risk and the spreading of information costs and other fixed costs to larger asset size. Significant economies of scale suggest technological factors as an important driver of banks' motivation in increasing asset size. In contrast to this result, Fries and Taci (2005) stated that size is not a matter for bank cost efficiency, as institutional condition is more important especially in the transition countries (Eastern Europe).

The capital is positive for efficiency and negative for cost efficiency. Well capitalized bank is more profitable and more cost efficient, which indicates the importance of capital for banking. This result is consistent with Lee and Hsieh (2013). This finding is similar to Sufian and Habibullah (2009) on the China banking market where capitalization has positive impacts on the profitability.

Liquidity is not significant for both models. It may be as the consequences of strict regulation policy in Indonesia bank. Banking authority set minimum liquidity requirements, which banks must follow. The regulation also requires banks to take into account the credit risk and other risk management indicator, such as funding concentration in their liquidity management. However, the result is consistent with the expectation.

For the policy of the bank to enter the microfinance business, the result is interesting to discuss. In terms of profitability, this strategy is positive and significant, indicating the contribution of this strategy increases profitability. Banks that complement their business lines with microfinance or focuse on microfinance are more profitable. It is a result of capability to exploit the interest differential. However, at the cost side, we find it positive, but not significant. It implies that the strategy to enter microfinance is not followed by efforts to improve efficiency. If the bank can improve efficiency, the profitability will be higher. In short, the strategy to enter the microfinance business improves profitability but not encourages the bank to be more efficient. In other words the profitability is a result of interest rate exploitation of the mass market only.

\section{CONCLUSION}

The Indonesian banking market has transformed very fast as a result of the Asian crisis in 1998. Stronger market mechanism means banks are required to financially perform better, especially after foreign investor taking over the ownership. Some banks transformed their business strategy into small business and mass 
market bank known as microfinance bank. They provide services such as saving and lending to small and micro enterprise and relatively poor clients. A successful experience of Bank Rakyat Indonesia (BRI) has been an example how microfinance bank is profitable and less prone to crisis.

The popularity of microfinance is a strategy for better performance. The ideal microfinance bank should be social businesses, meaning the bank doing microfinance not only for profit, but also for social mission. Commercial banks entering microfinance business should encourage the market to reduce the price of the small loan.

In general, we can conclude some points. The banks transforming their business model into microfinance banks are for profit motives not for social. This strategy has a positive impact on profitability, but no significant impact on operating cost efficiency. It means efforts to make it more cost efficient are needed, as it will provide better benefits for small borrowers. Over the impact of microfinance strategy, using a Breusch-Pagan test of independence, Chi-squared is 242.519 and significant at $1 \%$. It means the strategy is jointly significant to profitability and efficiency. Profitability is also related to the size of the bank. Its benefit comes from asset side, liability side and operation side. The capital strength is also significant for the profitability. It means that bank with stronger capital is more successful than lower capital banks. The bank spending too much on fixed assets will have lower profitability, as the capacity of equity for productive investment is lower and costs to maintain the fixed assets are expensive.

The Loan loss reserve to gross loan (LLRGL) is also significant for profitability and efficiency model. In the country where the bank is the main source of financing, failure to maintain credit quality is prone to failure. Asset size is significant for operating efficiency model. The asset size is negative and significant at $1 \%$, meaning that big banks enjoy lower cost of operation. This finding may imply that banking restructuring is necessary for improvement in efficiency.

Interestingly, the microfinance strategy (MFS) is not significant for bank efficiency. The strategy is positive for cost efficiency, but an effort to reduce the cost is still needed. Ban is should reduce interest margin as it is still higher compared to usual business loan. In general, banks entering microfinance business own higher equity capital to asset ratio (ETA). The ETA is also significant meaning the substantial effect of equity to cost efficiency. It means microfinance banking should put more capital for efficiency and stability. The results, in general, are consistent between the expected results and empirical ones. It is also in line to the established literature, such as Berger and De Young (1997), Tahir et al. (2012) and Athanasoglu, Brissimis and Delis (2008), Srairi (2009), Demirguc-Kunt and Maksimovic (1999), Sufian (2011), Dawood (2014), and Shaban, Duygun, Anwar and Akbar (2014). However, it is still not in line with the expectations of Murdoch (2000), Yunus (2011) and Baydas, Graham and Valenzuela (1997). It implies the need to be more socially oriented for the commercial banks entering microfinance business.

\section{REFERENCES}

1. Ahmed, I., Bhuiyan, A. B., Ibrahim, Y., Said, J., and Salleh, M. F. M. (2016). Social Accountability of Microfinance Institutions in South Asian Region. International Journal of Economics and Financial Issues, 6(3), 824-829.

2. Al Atoom, R. O., and Abu Zerr, A. E. (2012). Macro and microfinancial factors that assures Jordanian Microfinance Institutions' (MFIs) financial sustainability. European Journal of Economics, Finance and Administrative Sciences, 54, 146-160.

3. Athanasoglou, P., Brissimis, S., and Delis, M. (2008). Bankspecific, industry specific and macroeconomic determinants of bank profitability. International Financial Markets Institutions and Money, 18(2), 121-136. http://dx.doi.org/10.1016/j. intfin.2006.07.001
4. Ault, J. K., and Spicer, A. (2014) The institutional context of poverty: State fragility as a predictor of cross-national variation in commercial microfinance lending. Strategic Management Journal, 35(12), 1818-1838.

5. Bassem, B. (2009). Governance and performance of microfinance institutions in Mediterranean countries. Journal of Business Economics and Management, 10(1), 31-43. 
6. Baydas, M., Graham, D., \& Valenzuela, L. (1997). Commercial Banks in Microfinance: New Actors in the Microfinance World, Microenterprise Best Practices Project. USAID. Bethesda, Maryland: Development Alternatives, Inc.

7. Bounouala, R., and Rihane, C. (2014). Commercial banks in microfinance: entry strategies and keys of success. Journal of Investment Management and Financial Innovations, 11(1).

8. Berger, A. N., and De Young, R. (1997). Problem loans and cost efficiency in commercial banks. Journal of Banking and Finance, 21(6), 849-870.

9. Berger, A. N., and Di Patti, E. B. (2006). Capital structure and firm performance: A new approach to testing agency theory and an application to the banking industry. Journal of Banking \& Finance, 30(4), 1065-1102.

10. CGAP. (1998). Commercial Banks in Microfinance: New Actors in the Microfinance World. CGAP Focus, 12, July 1998.

11. Dawood, U. (2014). Factors impacting profitability of commercial banks in Pakistan for the period of (2009-2012). International Journal of Scientific and Research Publications, 4(3), 1-7.

12. Demirgüç-Kunt, A., and Huizinga, H. (1999). Determinants of commercial bank interest margins and profitability: some international evidence. The World Bank Economic Review, 13(2), 379-408.

13. Demirgüç-Kunt, A., \& Maksimovic, V. (1999). Institutions, financial markets, and firm debt maturity. Journal of financial economics, 54(3), 295-336.

14. Dichter, T. W., and Harper, M. (Eds.). (2007). Whats wrong with microfinance? Practical Action Pub.

15. Elaydi, R. and Harrison, C. (2010). Strategic motivations and choice in subsistence markets. Journal of Business Research, 63(6), 651-655. http://dx.doi.org/10.1016/ j.jbusres.2009.04.026.
16. Gardener, E., Molyneux, P., and Nguyen-Linh, H. (2011). Determinants of efficiency in South East Asian banking. The Service Industries Journal, 31(16), 2693-2719.

17. Greene, W. H. (2012). Econometric Analysis. 7th ed. Upper Saddle River, NJ: Prentice Hall.

18. Hughes, J. P., \& Mester, L. J. (2013). Who said large banks don't experience scale economies? Evidence from a risk-returndriven cost function. Journal of Financial Intermediation, 22(4), 559-585.

19. Kasman, A., Tunc, G., Vadar, G. \& Okan, B. (2010). Consolidation and Commerical Bank Net Interest Margins: Evidence from the old and new European Union Members and Candidate Countries. Journals of Economic Modelling, 27(3), 648-655.

20. Karim, M. Z. A. (2001). Comparative Bank Efficiency across Select ASEAN countries. ASEAN Economic Bulletin, 18(3), 289-304.

21. Lee, C. C., \& Hsieh, M. F. (2013). The impact of bank capital on profitability and risk in Asian banking. Journal of international money and finance, 32, 251-281.

22. Lee, C. C., \& Hsieh, M. F. (2013). The impact of bank capital on profitability and risk in Asian banking. Journal of international money and finance, 32, 251-281.

23. Lieberg, D., and Schwaiger, $M$. S. (2009). What Drives the Interest Rate Margin Decline in EU Banking - The Case of Small Local Banks. Kredit Und Kapital, 42(4), 509-538.

24. Martinez, C. (2015). Doing Well by Doing Good? Empirical Evidence from Microfinance (No. CFDWP06-2015). Centre for Finance and Development, The Graduate Institute.

25. McAllister, P. H. and McManus, D. (1993). Resolving the scale efficiency puzzle in banking. Journal of Banking \& Finance, 17(2), 389-405.
26. Mersland, R. and Strøm, R. O. (2010). Microfinance mission drift? World Development, 38(1), 28-36.

27. Molyneux, P. and Thornton, J. (1992). Determinants of European bank profitability: A note. Journal of banking \& Finance, 16(6), 11731178.

28. Shaban, M. A., Duygun, M. A., Anwar, M. B, Akbar, B. C. (2014). Diversification and banks' willingness to lend to small businesses: Evidence from Islamic and conventional banks in Indonesia. Journal of Economic Behavior and Organization, 103, 39-55. http://doi.org/10.1016/j. jebo.2014.03.021.

29. Shahriar, A. Z. M., Schwarz, S., \& Newman, A. (2015). Profit orientation of microfinance institutions and provision of financial capital to business start-ups. International Small Business Journal. http://doi. org/10.1177/0266242615570401.

30. Sufian, F., and Habibullah, M. S. (2009). Determinants of bank profitability in a developing economy: Empirical evidence from Bangladesh. Journal of business economics and management, 10(3), 207-217.

31. Srairi, S. A. (2009). Factors influencing the profitability of conventional and Islamic commercial banks in GCC countries. Review of Islamic Economics, 13(1), 5-30.

32. Tahir, I. M. Abdul and Haron, S. (2012). The Determinants of Bank Cost Inefficiency in ASEAN Banking. Jurnal Pengurusan, 36, 69-76.

33. Tan, Y., and Floros, C. (2012). Bank profitability and inflation: the case of China. Journal of Economic Studies, 39(6), 675-696.

34. Rosengard, J. K. (2004). Banking on social entrepreneurship: the commercialization of microfinance. Mondes en développement, 2(126), 25-36.

35. Yunus, M. (2011). Building social business: The new kind of capitalism that serves humanity's most pressing needs. PublicAffairs. 